\title{
Holocene environmental changes in Red River delta, Vietnam as inferred from the stable carbon isotopes and $\mathrm{C} / \mathrm{N}$ ratios
}

\author{
Nguyen Tai Tue ${ }^{1,2, *} *_{(\mathbb{D}}$, Dang Minh Quan $^{2}$, Pham Thao Nguren $^{2}$, \\ Luu Viet Dung ${ }^{2}$, Tran Dang QuY ${ }^{1,2}$ and Mai Trong Nhuan ${ }^{1,2}$ \\ ${ }^{1}$ Faculty of Geology, VNU University of Science, 334 Nguyen Trai Street, Thanh Xuan, Hanoi, Vietnam. \\ ${ }^{2}$ VNU Key Laboratory of Geoenvironment and Climate Change Response, 334 Nguyen Trai Street, Thanh Xuan, \\ Hanoi, Vietnam. \\ *Corresponding author.e-mail: tuenguyentai@gmail.com tuenguyentai@vnu.edu.vn
}

MS received 18 July 2017; revised 12 March 2018; accepted 18 April 2018; published online 10 December 2018

The present study applied stable carbon isotopes, $\mathrm{C} / \mathrm{N}$ ratios, and sedimentological indicators to reconstruct environmental changes during Holocene and to test the hypothesis that $\delta^{13} \mathrm{C}$ and $\mathrm{C} / \mathrm{N}$ ratios are accurate proxies of sea level change in the Red River delta (RRD), Vietnam. A $36 \mathrm{~m}$ long sediment core was mechanically drilled in the wave-dominated region of the RRD. The covariation of lithological characteristics, sediment grain-size distribution and geochemical proxies (LOI, TOC, C/N, $\delta^{13} \mathrm{C}$ ) suggested that the sediment core could be divided into six depositional environments, consisting of sub- and inter-tidal flats (formed before 8860 cal. year BP), shelf-prodelta, delta front slope (formed from 8860 to 2290 cal. year BP), delta front platform, tidal flat, and flood plain (from 2290 to 0 cal. year $\mathrm{BP}$ ). Covariation of $\delta^{13} \mathrm{C}$ and $\mathrm{C} / \mathrm{N}$ ratios in the sediment core allowed for tracing the origin of sedimentary organic carbon, which shifted from the dominance of mangroves and C3 plants at the suband inter-tidal flats to marine phytoplankton at the shelf-prodelta and delta front slope. The sedimentary sources of the delta front platform, tidal flat and flood plain were a mixture of phytoplankton and C3 plants, with the later source being dominant.

Keywords. Environmental change; stable isotopes; C/N ratios; Red River delta; Vietnam.

\section{Introduction}

Investigations of paleoenvironmental change during the Holocene in coastal areas aim to clarify characteristics of environmental change related to relative sea level rise (Wilson et al. 2005a, b), climatic change, and monsoonal variability (Meyers and Elisabeth 1999; Li et al. 2006; Zong et al. 2006). Studies on environmental change during the Holocene provide crucial information for simulating and predicting future effects of climate and environmental change (Wanner et al. 2008) and in understanding the interactions between humans and the environment ( $\mathrm{Li}$ et al. 2006). For example, sea level rise poses a major threat to coastal systems through sediment erosion, inundation stress and increased salinity to landward zones (Nicholls and Cazenave 2010). Therefore, reconstruction of relative sea level in coastal environments is fundamental to understanding past, present and future environmental change in these regions. Results can provide a mean to develop sea level rise models that 
can be used to explain patterns of climate-driven shifts of flora and fauna across coastal areas and to parameterize and predict future climate scenarios (Lambeck and Chappell 2001).

Sedimentary records in the large river deltas along Asian coast are useful to reconstruct the environmental and sea level change during Holocene epoch (Ta et al. 2002; Tanabe et al. 2003, 2006; Zong et al. 2006; Liu et al. 2014). These studies have shown that the Asian deltas had experienced multiple transgressions and regressions, and climate change ( $\mathrm{Li}$ et al. 2006; Zong et al. 2006). Factors affecting the environmental and sea level changes of the deltas have been determined to be hydrodynamics, sediment discharge, sea-level fluctuation, and monsoon variability (Tanabe et al. 2006; Zong et al. 2006; Elizabeth et al. 2007).

Many paleoenvironmental proxies achieved, including stable isotopes, pollen, and sedimentary texture have been widely used to reconstruct the Holocene environmental changes and monsoonal variability from Mekong River delta, Vietnam (Ta et al. 2002), Red River delta (RRD), Vietnam (Li et al. 2006; Tanabe et al. 2006; Tanaka et al. 2011), Pearl River estuary, China (Zong et al. 2006), and Mersey estuary, UK (Wilson et al. 2005b). Among these proxies, stable carbon isotopes $\left(\delta^{13} \mathrm{C}\right)$ and $\mathrm{C} / \mathrm{N}$ ratios analyzed from sedimentary organic matter have been successfully used to improve the understanding of sedimentary organic matter provenance and sedimentation processes, and to reconstruct environmental changes in coastal environments (Wilson et al. 2005a, b; Lamb et al. 2006 , 2007; Reotita et al. 2014).

Our primary goals in this study are to use $\delta^{13} \mathrm{C}$ values, $\mathrm{C} / \mathrm{N}$ ratios, and sedimentological indicators to reconstruct the environmental changes in Holocene and to test the hypothesis that $\delta^{13} \mathrm{C}$ values and $\mathrm{C} / \mathrm{N}$ ratios in Holocene sediments are accurate proxies of the past sea level change in the RRD.

\section{Materials and methods}

\subsection{Regional setting of Red River delta}

The present study was conducted within the RRD in northern Vietnam (figure 1), which located in the western coast of the Gulf of Bac Bo (Tonkin). The catchment area of the Red River is $156,451 \mathrm{~km}^{2}$, ranking as the second largest river in Vietnam (Le et al. 2007) and the fourth largest delta in southeast Asia, after the Mekong, Irrawaddy, and Chao Phraya deltas (Chan et al. 2012). The RRD is surrounded by mountains, which are composed of Pre-Quaternary bedrock (figure 1). The RRD is divided into three sub-systems based on topography and hydraulic processes, consisting of wave-, tide-, and fluvialdominated sub-systems (Mathers and Zalasiewicz 1999; Tanabe et al. 2006). The wave-dominated sub-system spreads to the southern part of the delta with an alternation of beach ridges and muddy tidal lagoon deposits. The tide-dominated sub-system reaches into the northeastern part of the delta predominantly consisting of tidal flats, marshes, and tidal creeks/channels. The fluvial sub-system consists of meandering rivers, meandering levee belts, floodplain, and fluvial terraces (figure 1). The Quaternary depression in the RRD was mainly filled by continental deposits in five geological cycles: early Pleistocene (Le Chi Formation), middle to late Pleistocene (Hanoi Formation), late Pleistocene (Vinh Phuc Formation), early to middle Holocene (Hai Hung Formation) and late Holocene (Thai Binh Formation) (Nghi et al. 1991). The Holocene sediments were earlier divided into fluvial sediments composed of gravelly sand and mottled clay, tide-influenced estuarine sediments containing shell and wood fragments, and deltaic sediments consisting of tide-influenced sand and mud deposits (Tanabe et al. 2006). The Red River is $1138.5 \mathrm{~km}$ in length, with the majority of water and sediment fluxes flowing into the Gulf of Tonkin. Water and sediment fluxes are highly variable with seasonal changes in monsoonal precipitation. The mean annual rainfall of the RRD is $1600 \mathrm{~mm}$, in which $85-95 \%$ of the total yearly rainfall occurs during the rainy season lasting from May to October (Le et al. 2007). Annual suspended sediment load of the entire Red River is 100 million tons, ranking among the 15 largest sedimentary discharges in the world (Milliman and Meade 1983).

\subsection{Sediment core sampling and processing}

A continuous sediment core (core VL-01) was recovered by a rotary drill (10 $\mathrm{cm}$ in diameter) from the wave-dominated system in the RRD (figure 1). The geographical location of the core VL-01 was $106^{\circ} 24^{\prime} 7.46^{\prime \prime} \mathrm{E}$ and $20^{\circ} 25^{\prime} 39.86^{\prime \prime} \mathrm{N}$ with an altitude of $0.5 \mathrm{~m}$. The total core length was $36 \mathrm{~m}$, with a core recovery of $80.1 \%$. Immediately following collection, the sediment core was placed in PVC tubes, 


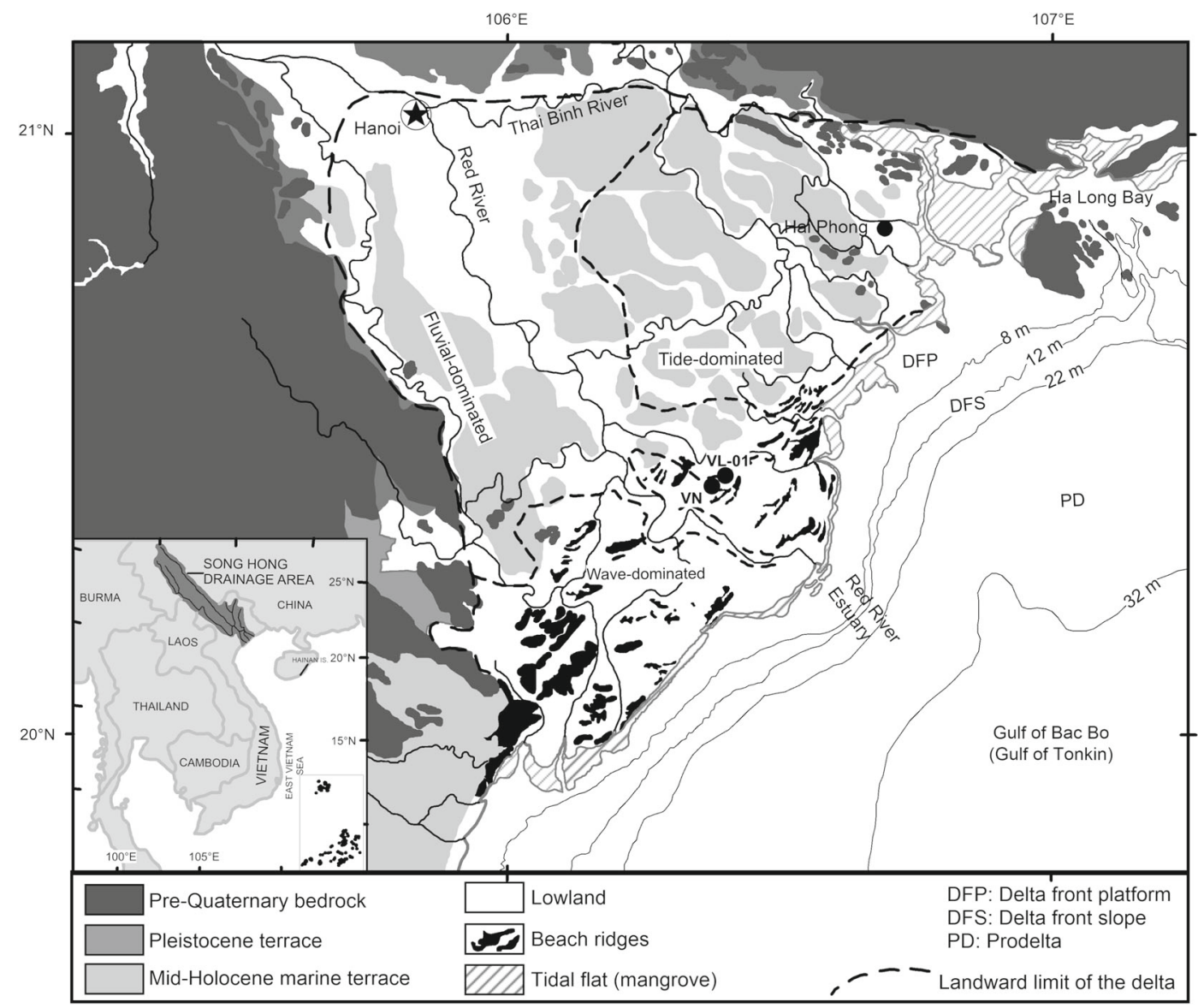

Figure 1. Map showing the major geological characteristics of the Red River delta, Vietnam (modified from Tanabe et al. 2006), and geographical locations of core VL-01 (this study) and core VN in the earlier studies (Li et al. 2006; Tanabe et al. 2006).

sealed in aluminum foil and plastic wrap in order to minimize the gas exchange, then placed in a cooler box and transported to the laboratory. In the laboratory, the sediment core was split and examined in terms of general lithological characteristics based on grain size, color, sedimentary structure, texture and fossils. Next, the outer layer $(\sim 0.5 \mathrm{~cm}$ in thickness) was removed and sliced into 154 samples at $20 \mathrm{~cm}$ intervals. The sliced sediments were packed in labeled polyethylene bags and frozen for further processing and analyses.

The lithological characteristics of core VL-01 were closely correlated with the adjacent core VN (figure 1) from an earlier study by Tanabe et al. (2006). Therefore, the geochronology of the sediment core was calculated based on the sedimentation rates (figure $2 \mathrm{C}$ ), which were established by fifteen accelerator mass spectrometry (AMS) ${ }^{14} \mathrm{C}$ for this region (Tanabe et al. 2006). Results indicated that the core length can correspond to the last 11,260 years.

\subsection{Sample preparation and analysis}

For analysis of sediment grain sizes, five grams of fresh sediments were put into a beaker. The sediment sample was then pretreated with an $\mathrm{H}_{2} \mathrm{O}_{2}$ solution $(30 \%)$ and $1 \mathrm{~N} \mathrm{HCl}$ for $24 \mathrm{hr}$ to assure complete removal of organic matter and carbonates. Prior to analysis, $10 \mathrm{ml}$ of distilled water was added and dispersed using an ultrasonic cleaner for 3 min. Sediment grain sizes were analyzed using an automatic laser diffraction particle size analyzer LA-950V2 (HORIBA Co.), with the measurement range of $0.01-3000 \mu \mathrm{m}$. Each sediment sample was analyzed in triplicate to yield the percentages of the related size fractions of a sample with a relative error of less than $1 \%$. Mean value of sediment grain sizes (Md), sand, silt and clay fractions were computed to represent the lithological characteristics of the sediment samples. Other sedimentary parameters, consisting of sorting, skewness and kurtosis $(\mathrm{KG})$ were calculated using a grain size distribution 

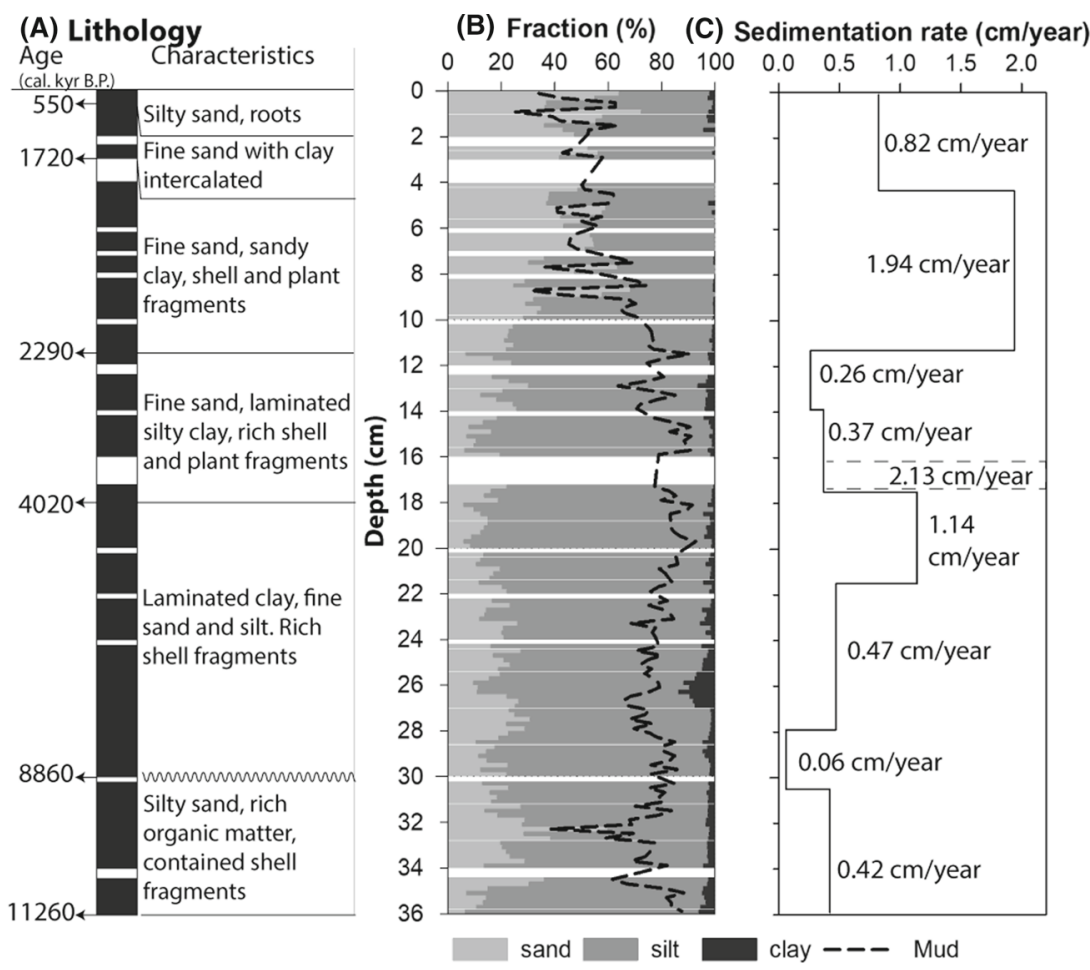

Figure 2. (A) Lithological characteristics of core VL-01; (B) sediment facies of the sediment core; and (C) sedimentation rates of the study area were calculated by linear interpolation between radioactive ${ }^{14} \mathrm{C}$ ages and depth (Li et al. 2006 ; Tanabe et al. 2006).

and statistic program (GRADISTAT) by Blott and Pye (2001).

For loss on ignition (LOI), stable carbon isotopes $\left(\delta^{13} \mathrm{C}\right)$ and elemental analysis (TN and TOC), sediment samples were completely dried at $60^{\circ} \mathrm{C}$ in an electric oven, and subsequently pulverized using an agate mortar and pestle. The visible organic matter particles (roots and small plant matter) and shell fragments were manually removed from sediment samples using stainless steel forceps. The measurement of LOI followed the methods outlined by Tue et al. (2014). Briefly, two grams of the pulverized sediments was combusted at $550^{\circ} \mathrm{C}$ in a temperature-monitored muffle furnace for $5 \mathrm{hr}$. The LOI values were obtained by difference between the weight from before and after combustion at $550^{\circ} \mathrm{C}$. For $\delta^{13} \mathrm{C}$, TN and TOC analysis, the pulverized sediments were placed in an Eppendorf tube and treated with $1 \mathrm{~N} \mathrm{HCl}$ for $24 \mathrm{hr}$ to remove carbonates. After acid treatment, the samples were thoroughly rinsed by Milli-Q filtered distilled-deionized water and re-dried at $60^{\circ} \mathrm{C}$ in an electric oven for $24 \mathrm{hr}$. The $\delta^{13} \mathrm{C}$, TN and TOC were simultaneously analyzed using an elemental analyzer (EuroVector EA3000) connected to an isotope ratio mass spectrometer (Nu-Perspective Instrument). During analysis, a certified reference material (L-alanine) was used to quantify the analytical results. Analytical errors were $0.05 \%$ for $\delta^{13} \mathrm{C}, 0.05 \%$ for TN, and $0.1 \%$ for TOC.

\section{Results}

\subsection{Lithological characteristics}

Sediments of core VL-01 were mainly composed of sand, silt and clay, which ranged from 6.0-72.5, 25.3-92.7, and 0.1-13.7\%, respectively (figure 2B). Sediment facies of core VL-01 can be classified into silt, sandy silt and silty sand. The core was divided into six sections according to lithology, color and grain size parameters as follows.

\subsubsection{Core section 1: From 36.0 to $30.1 \mathrm{~m}$ (11,260-8860 cal. year BP)}

This section was characterized by silty sand that was reddish-gray in color and composed of very fine sand and clay lamination (figure 2A). Mud content gradually decreased from the core bottom to a minimum value at the depth of $32.3 \mathrm{~m}$ (figure $2 \mathrm{~B}$ ). The mean sediment grain size $(\mathrm{Md})$ tended to gradually decrease upward, ranging from 26.7 to $74.0 \mu \mathrm{m}$ with an average of $39.1 \mu \mathrm{m}$ (figure $3 \mathrm{~A}$ ). In this 


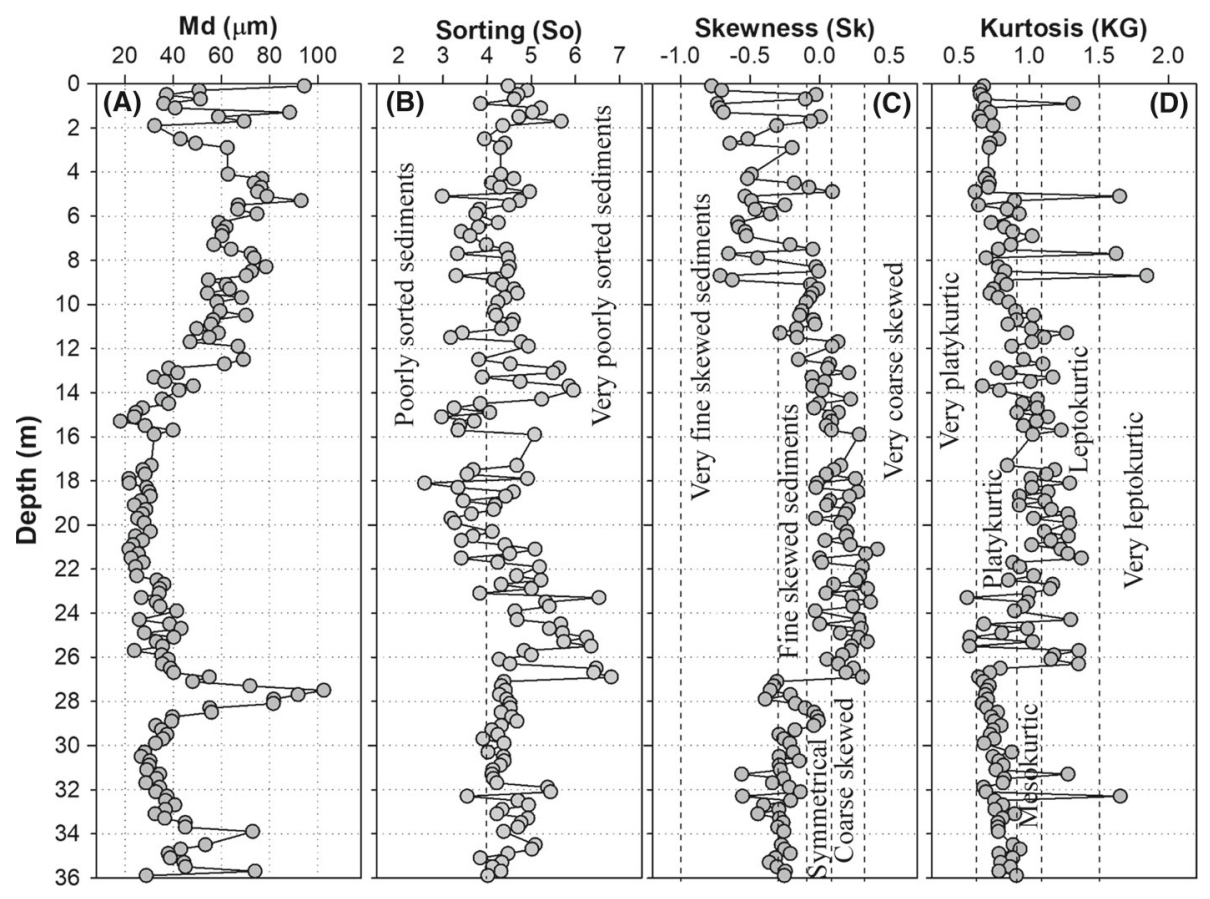

Figure 3. Sedimentary parameters in grain-size distributions from core VL-01 showing variations with depth.

section, the mean sorting value (So) was $4.45 \pm$ 0.46 , classifying it as being very poorly-sorted sediments (figure $3 \mathrm{~B}$ ). The skewness (Sk) of the data showed a mean of $-0.29 \pm 0.10$, characterizing it as very fine skewed sediments to fine skewed sediments (figure 3C). Kurtosis values (KG) tended to increase upward, with two exceptions being values at the depth of 32.3 and $31.3 \mathrm{~m}$ (figure 3D). The KG values varied from 0.67 to 1.66 , with an average of $0.86 \pm 0.19$, classified as platykurtic sediments.

\subsubsection{Core section 2: From 30.1 to $18.9 \mathrm{~m}$ (8860-4020 cal. year BP)}

This section was separated by an underlying sediment section from surface erosion (figure 2A), which was previously determined by Tanabe et al. (2006). Further evidence of the surface erosion came from $\mathrm{C} / \mathrm{N}$ ratios and $\delta^{13} \mathrm{C}$ values (figure $4 \mathrm{C}$ and $\mathrm{D})$. At the erosion surface, the sediments consisted of predominantly clay with laminated fine sand and silt lenses, and rich in shell fragments (figure 2A). Clay content was the highest and mud content tended to slightly vary upward (figure 2B). Mean sediment grain size markedly increased from the erosion surface to $27.5 \mathrm{~m}$ in depth, before continuously decreasing to the depth of $18 \mathrm{~m}$ (figure $3 \mathrm{~A}$ ). Based on the variation of So values, sediments were divided into types, consisting of very poorly sorted sediments from 30 to $21.9 \mathrm{~m}$ and poorly sorted sediments in the rest of the layers (figure 3B). Sk values fluctuated in a small range, but can be divided into symmetrical and coarse skewed sediments (figure 3C). The $\mathrm{KG}$ values indicated for platykurtic sediments from 30 to $26.5 \mathrm{~m}$ in depth, and fluctuated from very platykurtic to leptokurtic sediments in the upper layers (figure 3D).

\subsubsection{Core section 3: From 18.9 to $11.7 \mathrm{~m}$ (4420-2290 cal. year BP)}

This section was characterized by gray and black sand and laminated silty clay that was rich in shell and plant matter (figure 2A). Mud content maintained high values from the previous section but displayed a decreased trend (figure 2B). The $\mathrm{Md}$ values were lowest and gradually increased upward (figure 3A). The So values fluctuated widely and were classified into poorly sorted sediments to very poorly sorted sediments (figure $3 \mathrm{~B}$ ). Skewness values displayed a low variation through time but slightly decreased upward (figure 3C), indicating symmetrical and coarse-skewed sediments. Kurtosis values showed relatively low variation and closely matched that of mesokurtic sediments (figure 3D). 


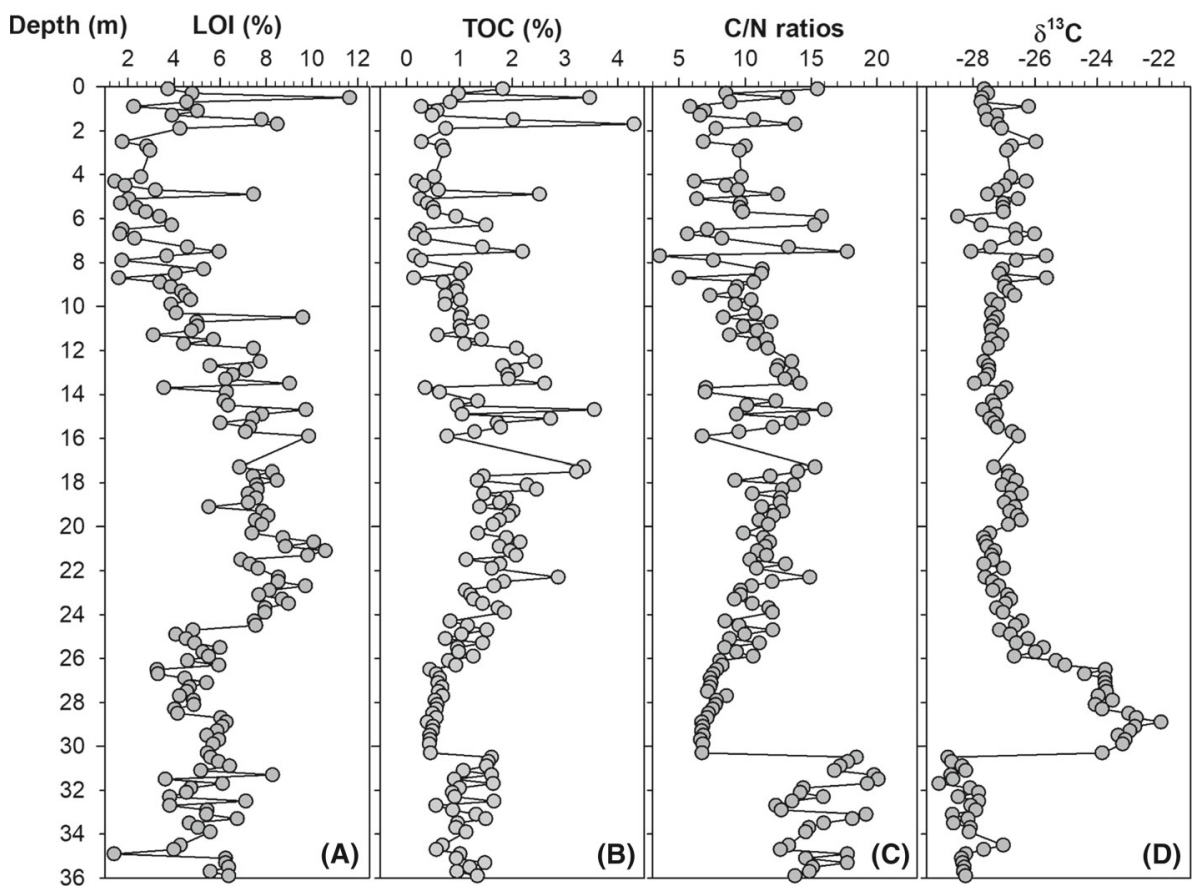

Figure 4. Measurements of LOI (\%), TOC (\%), C/N ratios and $\delta^{13} \mathrm{C}(\%)$ in core VL-01 with depth.

\subsubsection{Core section 4: From 11.7 to $4.1 \mathrm{~m}$ (2290-1720 cal. year BP)}

This section was composed of gray silt, fine sand and clay sediments and was abundant in plant matter (figure 2A). The sand fraction continuously increased upward and displayed an opposite trend with mud content (figure 2B). Mean sediment grain size values tended to increase and displayed a twofold increase at depths of 8.7 and $5.4 \mathrm{~m}$ (figure $3 \mathrm{~A}$ ). Variation in So values remained low, mainly indicating very poorly sorted sediments (figure $3 \mathrm{~B}$ ). Skewness values fluctuated with a decreasing trend and were an indication of very fine to fine-skewed sediments (figure 3C). Kurtosis values fluctuated in some sediment layers, but still maintained a decreasing trend upward (figure 3D).

\subsubsection{Core section 5: From 4.1 to $0.5 \mathrm{~m}$ (1720-550 ca. year BP)}

The section was composed of gray fine sand, silt and peat lenses (figure 2A). Mud content varied over a small range and had a decreasing trend (figure 2B). Inversely, sand content slightly increased upward and reached a maximum at the top sediment layer of this section (figure $2 \mathrm{~B}$ ). The $\mathrm{Md}$ values varied in across a wide range, continuously decreasing from underlying facies to the depth of $1.9 \mathrm{~m}$, and then markedly increasing at the depth of $1.3 \mathrm{~m}$ (figure $3 \mathrm{~A}$ ). The So values tended to slightly increase from underlying facies and reached a peak at a depth of $1.7 \mathrm{~m}$ (figure $3 \mathrm{~B}$ ). In this layer, most of the sediment was categorized as very poorly sorted (figure 3B). Skewness values fluctuated widely from very fine to fine-skewed sediments (figure $3 \mathrm{C}$ ). Kurtosis values varied marginally with the exception at depth $0.9 \mathrm{~m}$ in which there was an indication of platykurtic sediments (figure 3D).

\subsubsection{Core section 6: From 0.5 to $0 \mathrm{~m}$ (550-0 cal. year BP)}

Sediments were reddish brown clay silt, fine sand and an abundance of fine roots. Md values tended to increase to the sediment core surface (figure $3 \mathrm{~A}$ ). Based on So, Sk and KG values, sediments were classified as very poorly sorted, very fine skewed and consisting of platykurtic sediments (figure 3B-D).

\subsection{Geochemical proxies (LOI, TOC, $C / N, \delta^{13} C$ )}

\subsubsection{Loss on ignition (LOI)}

Below the depth of $30.1 \mathrm{~m}$, LOI values fluctuated around the mean of $4.4 \pm 2.2 \%$. LOI tended to slightly decrease at the depth of $26.7 \mathrm{~m}$, then increased to a maximum at $21.3 \mathrm{~m}$. LOI continuously decreased between 21.3 and $4.1 \mathrm{~m}$, then 

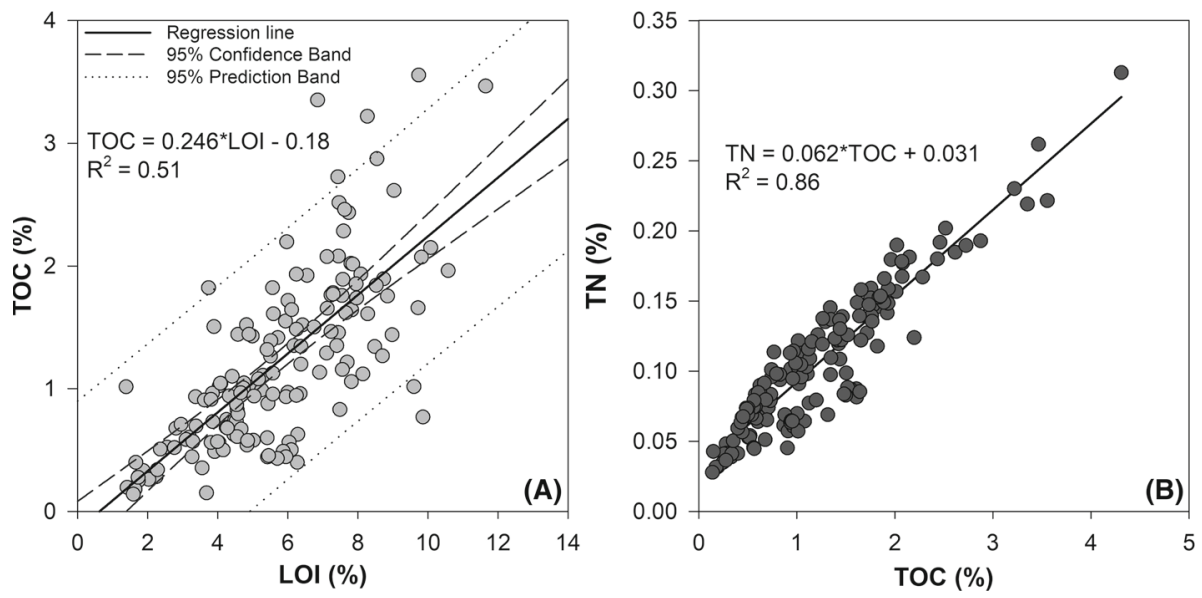

Figure 5. Relationship between LOI and TOC (A); TOC and TN (B). A strongly positive correlation between TOC and $\mathrm{TN}$ indicating the negligible contribution of inorganic nitrogen to $\mathrm{TN}$ in calculating the $\mathrm{C} / \mathrm{N}$ ratios.

slightly increased again in the surface sediments (figure 4A).

\subsubsection{Total organic content (TOC)}

TOC content slightly fluctuated at depths below $30.1 \mathrm{~m}$ with a mean of $1.1 \pm 0.4 \%$. TOC content suddenly decreased at the depth of $30.3 \mathrm{~m}$, then varied over a small range from 30.3 to $26.5 \mathrm{~m}$, and then gradually increased from 26.5 to $17.3 \mathrm{~m}$. Between 17.3 and $4.1 \mathrm{~m}$ in depth, TOC content tended to decrease with the exception of three points at 14.7, 7.5 and $4.9 \mathrm{~m}$ in depth (figure $4 \mathrm{~B}$ ). TOC values tended to have higher values at the surface soil which contained a higher proportion of rootlets.

TOC content was positively correlated with LOI content (figure 5A) and TN (figure 5B). The regression line of TOC and TN passed very close to the origin $(0,0)$, indicating that the inorganic nitrogen content was an insignificant contribution to the TN pool and thus can be disregarded (Hedges et al. 1986; Andrews et al. 1998). Therefore, the TN can be used instead of organic nitrogen for calculating $\mathrm{C} / \mathrm{N}$ ratios to examine sedimentary sources and to reconstruct the paleoenvironment (Müller and Mathesius 1999).

\subsection{3 $C / N$ ratios}

Below $30.1 \mathrm{~m}$ in depth, $\mathrm{C} / \mathrm{N}$ ratios fluctuated slightly between 12.2 and 20.1 with a mean of $15.6 \pm 2.9$ (figure $4 \mathrm{C}$ ). $\mathrm{C} / \mathrm{N}$ ratios suddenly dropped to a value of 6.7 at the erosion surface. In the section between 30.1 and $17.3 \mathrm{~m}, \mathrm{C} / \mathrm{N}$ ratios increased slightly upward, with an average of $10.0 \pm 2.3$. Between the depth of 17.3 and $7.7 \mathrm{~m}, \mathrm{C} / \mathrm{N}$ ratios tended to decrease slightly and reached a maximum of 3.5 at the depth of $7.7 \mathrm{~m}$. From $7.7 \mathrm{~m}$ to the core surface, $\mathrm{C} / \mathrm{N}$ ratios fluctuated widely around a mean of 10.0 (figure $4 \mathrm{C}$ ).

\subsubsection{Stable isotope carbon $\left(\delta^{13} C\right)$}

The $\delta^{13} \mathrm{C}$ values ranged from -29.1 to $-22.5 \%$ with an average of $-26.8 \pm 1.4 \%$. It showed an inverse trend with $\mathrm{C} / \mathrm{N}$ ratios (figure $4 \mathrm{D}$ ). Below the depth of $30.5 \mathrm{~m}, \delta^{13} \mathrm{C}$ values had small fluctuations around the mean of $-28.1 \pm 0.9 \%$. At the erosion surface, $\delta^{13} \mathrm{C}$ values suddenly increased to $-23.8 \%$ at the depth of $30.3 \mathrm{~m}$, then gradually increased and formed a peak of $-21.9 \%$ at $28.9 \mathrm{~m}$ in depth. From this depth, $\delta^{13} \mathrm{C}$ values continuously decreased to the depth of $20.3 \mathrm{~m}$. The $\delta^{13} \mathrm{C}$ was relatively invariant between 20.3 and $8.7 \mathrm{~m}$ in depth, then displayed small variation around the mean of $-27.1 \%$ to the surface sediment.

\section{Discussion}

\subsection{Sources of the organic matter}

Determination of sedimentary organic matter sources can provide new insights into sedimentation processes (Lorente et al. 2014), the paleoenvironment (Reotita et al. 2014), marine-terrestrial transport (Liu et al. 2016), and changes in sea level (Wilson et al. 2005b). The $\delta^{13} \mathrm{C}$ and $\mathrm{C} / \mathrm{N}$ ratios have been used to determine the provenance of sedimentary organic matter from the marine environment (Amano et al. 2006), estuary (He et al. 2010), coastal lagoon (Müller and Mathesius 1999; Reotita et al. 2014), inter-tidal zone (Wilson et al. 


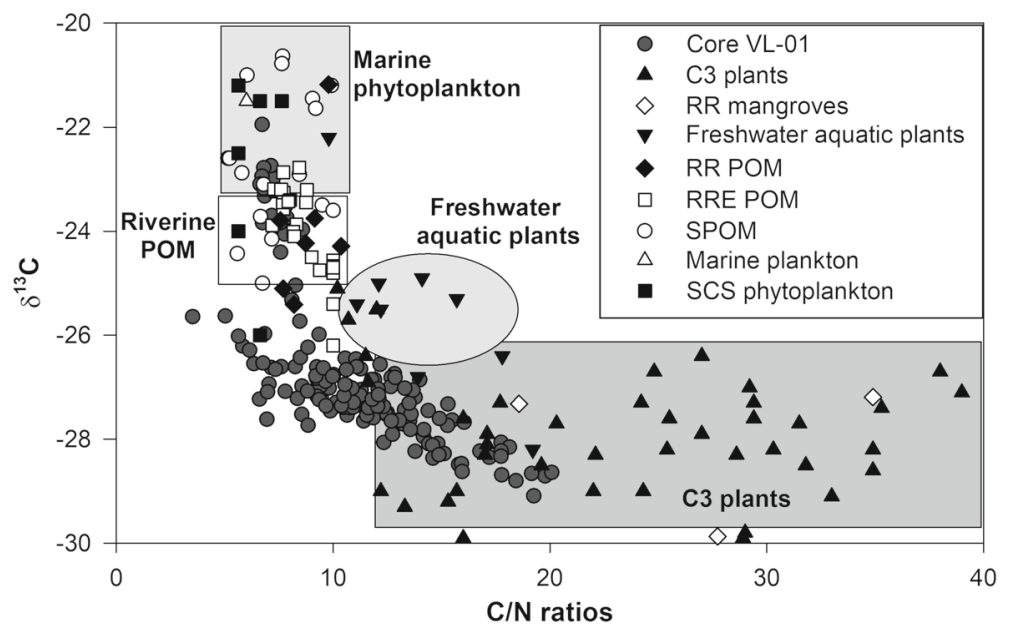

Figure 6. Comparison of $\mathrm{C} / \mathrm{N}$ ratios and $\delta^{13} \mathrm{C}$ in the sediment core VL-01 to those of organic carbon sources. $\mathrm{C} / \mathrm{N}$ ratios and $\delta^{13} \mathrm{C}$ of $\mathrm{C} 3$ plants (plants with C3 photosynthesis pathways) were reported in Meyers and Elisabeth (1999), Cloern et al. (2002), Elizabeth et al. (2007). RR mangroves, RR POM, and RRE POM denote for present-day mangroves growing in the Red River estuary, particulate organic matter in the Red River, and particulate organic matter in the Red River estuary, respectively (Tue et al. 2012). SPOM denotes suspended organic matter in river (Andrews et al. 1998). Marine phytoplankton and fresh water aquatic plants (Cloern et al. 2002) and SCS phytoplankton denotes phytoplankton from the South China Sea (Liu et al. 2007).

2005a) and delta plain (Liu et al. 2014). Generally, $\mathrm{C} / \mathrm{N}$ ratios of organic matter originated from freshwater algae, marine phytoplankton and microalgae are often $<10$, while those originating from terrestrial plants, freshwater plants and detrital organic matter are $>10$ (Lamb et al. 2006; figure 6 ). It should be noted that the leaching and degradation processes can modify $\mathrm{C} / \mathrm{N}$ ratios in sedimentary organic matter (Andrews et al. 1998; Müller and Mathesius 1999; Wilson et al. 2005b; Lamb et al. 2006; Tue et al. 2011). Yet, the C/N ratios and $\delta^{13} \mathrm{C}$ could be used together to determine the source of sedimentary organic carbon and to reconstruct the paleoenvironment. Plants are divided into three major groups of C3, C4 and CAM plants, which have distinct ranges in their $\delta^{13} \mathrm{C}$ due to differences in their respective photosynthetic pathways (O'Leary 1981). The $\delta^{13} \mathrm{C}$ values of $\mathrm{C} 3$ and $\mathrm{C} 4$ plants vary from -33.0 to $-23.0 \%$ and from -15.0 to $-9.0 \%$, respectively, with marine phytoplankton having a range between -22.0 and $-18.0 \%$ (Lamb et al. 2007). Thus, sedimentary organic matter sources can be effectively distinguished by using a combination of $\mathrm{C} / \mathrm{N}$ ratios and $\delta^{13} \mathrm{C}$ values.

The inverse relationship between $\mathrm{C} / \mathrm{N}$ ratios and $\delta^{13} \mathrm{C}$ in core VL-01 (figure 6) was similar to those reported in sediment cores (Tue et al. 2011) and surface sediments (Tue et al. 2012) from coastal mangrove forests in the RRD. The bi-plot of $\mathrm{C} / \mathrm{N}$ ratios and $\delta^{13} \mathrm{C}$ showed an absence of $\mathrm{C} 4$ plant material in the RRD during the Holocene. The sedimentary organic matters in core VL-01 mainly originated from terrestrial plants (C3, mangrove and aquatic plants), marine phytoplankton and riverine particulate organic matter (figure 6). Our results show that $38 \%$ of the sediment samples likely originated from C3 plants suggesting terrestrial sources, whereas only $12 \%$ of the sediment samples had ranges of $\mathrm{C} / \mathrm{N}$ ratios and $\delta^{13} \mathrm{C}$ indicative of marine phytoplankton. The remaining sediment samples were scattered into the zone between marine phytoplankton and C3 plants, indicating a mixture of terrestrial plants and marine phytoplankton (Lamb et al. 2007). Within core sediment section between 36.0 and $30.1 \mathrm{~m}$, low $\delta^{13} \mathrm{C}$ values $<-27.0 \%$ and high $\mathrm{C} / \mathrm{N}$ ratios $>12$ suggested terrestrial C3 plants were an important component of the sediments. The noticeable shift in $\delta^{13} \mathrm{C}$ values and $\mathrm{C} / \mathrm{N}$ ratios at the erosion surface indicated that the source of sedimentary organic carbon shifted from C3 plants to marine phytoplankton (Lamb et al. 2007). Between 30.1 and $18.9 \mathrm{~m}$ in depth, the variation of $\delta^{13} \mathrm{C}$ values and $\mathrm{C} / \mathrm{N}$ ratios indicated that marine phytoplankton contributed a large proportion to the lower sediment layers, then decreased upward. In this, the increasing $\delta^{13} \mathrm{C}$ values and concomitant sharp decrease in $\mathrm{C} / \mathrm{N}$ ratios from 30.1 and $26.3 \mathrm{~m}$ indicated a strong intensification of the marine phytoplankton source. Between 26.3 and $18.9 \mathrm{~m}$ in depth, the slightly decreasing $\delta^{13} \mathrm{C}$ values and increase in $\mathrm{C} / \mathrm{N}$ ratios 
indicated a decrease in marine phytoplankton contribution to sedimentary organic matter. Between 18.9 and $11.7 \mathrm{~m}$ in depth, $\delta^{13} \mathrm{C}$ values displayed a small variation around a mean of $-27.2^{\circ} \%$ and $\mathrm{C} / \mathrm{N}$ ratios fluctuated around the mean of 11.9 , indicating that terrestrial $\mathrm{C} 3$ plants contributed a significant proportion to the sedimentary organic matter (figure 6). From $11.7 \mathrm{~m}$ in depth to surficial sediments the slight increase in $\delta^{13} \mathrm{C}$ values and $\mathrm{C} / \mathrm{N}$ ratios together indicated a decreasing influence of terrestrial C3 plant matter, with proportional contribution likely from increasing freshwater aquatic plants and/or estuarine particulate organic matter.

\subsection{Evolution of the depositional environment during the Holocene epoch}

The sedimentary environment of the RRD resulted from the interaction of two factors of sea level change and fluvial inputs. The lithological characteristics in core VL-01 were similar to those of core $\mathrm{VN}$ in the previous study in this area (Tanabe et al. 2006). Results indicated that the sedimentation and environmental history from the core VL-01 and core VN areas are very likely derived by the same mechanisms.

The changes in sedimentary parameters $(\mathrm{Md}$, So, $\mathrm{Sk}, \mathrm{KG}$ ) describing sediment grained-size distributions have long been used to reconstruct the sedimentation environments (Visher 1969; McLaren and Bowles 1985), which reported that the Md, So, Sk of sediment grain-sizes are controlled by the direction of transport and the sedimentary processes of winnowing, selective and total deposition. In the present study, the Md values showed that the sediments in core VL-01 were categorized from fine silt to very fine sand, with a dominance of very coarse and coarse silt (figure $2 \mathrm{~B}$ ). This pattern indicated the sediments were generally deposited at environmental conditions from low to high energy (McLaren and Bowles 1985). Therefore, the sediment textures may be linked with the hydrological patterns and processes of riverine and sea-level change.

During the early Holocene (from 11,260 to 8860 cal. year BP), the sea level was $31 \mathrm{~m}$ below present and annually increased at a relatively constant rate of about $9 \mathrm{~mm}$ in the Vietnam Sea (Tjallingii et al. 2014). Therefore, the reddish gray color of the sediments below $30.1 \mathrm{~m}$ in depth indicated erosion processes during lowstands. The upward decreasing trends of mud content (figure 2B), Md, sorting, skewness and kurtosis (figure 3) illustrated the prevalence of coarse silt and fine sand sediments that were mainly formed in high-energy environments (Rajganapathi et al. 2013). During this period, C/N ratios had an upward increase with a mean value of 16 , indicating that sediment organic matter mainly originated from terrestrial plants (Lamb et al. 2007). The sedimentary $\delta^{13} \mathrm{C}$ values varied in a small range with a mean of $-28.3 \%$ which was very similar to the present mangrove signatures living in the coastline of the RRD (Tue et al. 2012), suggesting that mangroves may have been major sources of sedimentary organic carbon. Therefore, this stage can be considered as the sub- and intertidal environment with a high frequency of tidal flooding (Tanabe et al. 2006; Tue et al. 2011).

During the middle Holocene (from 8860 to 2290 cal. year BP), the sediment core could be divided into two distinguish sections based on lithological characteristics, sediment texture and geochemical proxies. At the lowest part of this section, the sudden decrease in the $\mathrm{C} / \mathrm{N}$ ratios and increase in $\delta^{13} \mathrm{C}$ values indicated that sedimentary organic matter composition suddenly shifted from C3 plants to a predominance of marine phytoplankton (Wilson et al. 2005a; He et al. 2010). Therefore, this sediment facies could be considered as a ravinement surface formed during the transition (Tanabe et al. 2003, 2006; Tanaka et al. 2011). With the acceleration of sea level rise between 8860 and 4020 cal. year BP, the RRD was gradually submerged, leading to the paleo-water depth of core VL-01, which reached to ca. $30 \mathrm{~m}$ at the period from 7000 to 6000 cal. year BP (Tanabe et al. 2006). The present results showed that Md values gradually increased between 30.1 and $27.5 \mathrm{~m}$ in depth (figure 3A), indicating that the transgressive sand sheet was overlain the erosion surface (figure 2B). During this period, characteristics of fine skewed and symmetrical sediments suggest a lower energy environment and various sources of sediment inputs (figure $3 \mathrm{C}$ ). The lowest $\mathrm{C} / \mathrm{N}$ ratios and the highest $\delta^{13} \mathrm{C}$ values in this core section indicated that the sources of sedimentary organic carbon mainly originated from marine phytoplankton (figure 6). This pattern suggests the sediments were deposited under relatively high sea levels following transgression. This finding was similar to that observed for the peak of marine ostracod assemblages (biofacies) in the VN core from the Red River delta (Tanaka et al. 2011). Results indicated that the highest sea level may have been 
obtained in the sediment layers from 28.7 to $26.7 \mathrm{~m}$ in depth (or from 7200 to 5680 cal. year BP), which is consistent with a previous finding in the wavedominated region of the RRD (Tanaka et al. 2011). The small variation in $\mathrm{Md}$ and $\mathrm{Sk}$ values from 26.7 to $18.7 \mathrm{~m}$ in depth (from 5680 to 4020 cal. year BP) indicated low hydrodynamic energy. The dominant mesokurtic and leptokurtic nature of the sediments showed that coarser-grained sizes were continuously added after the winnowing and retention action of tidal currents. The $\mathrm{C} / \mathrm{N}$ ratios showed a linear increase with depth, whilst, $\delta^{13} \mathrm{C}$ values varied in across a small range (figure $4 \mathrm{C}$ and $\mathrm{D}$ ). These data indicate that the core section from 30.1 to $18.7 \mathrm{~m}$ could be defined as a shelf-prodelta environment. Along with the rise in sea level, the sand fraction and $\mathrm{Md}$ values slightly increased in the upper part of the middle Holocene at the depth from 18.7 to $11.7 \mathrm{~m}$ (figure 3A), reflecting higher hydrodynamic energy (McLaren and Bowles 1985). The Sk values tended to an upward shift from coarse to fine skewed nature of sediments, indicating the introduction of fine-grained particles or removal of coarse-grained particles and high riverine input (Friedman 1961). Additionally, $\mathrm{C} / \mathrm{N}$ ratios and $\delta^{13} \mathrm{C}$ values were overlaid between marine phytoplankton and C3 plant production, or accumulated from riverine particulate organic matter (figures 5 and 6 ). The data suggest that the fluvial sediments from the RRD tend to have a high influence on the sediment facies during this period (Maren and Hoekstra 2005; Duc et al. 2007). The gradual change in lithological characteristics, sedimentary textures, $\mathrm{C} / \mathrm{N}$ ratios and $\delta^{13} \mathrm{C}$ values from the underlying sediment facies indicated that this section was formed in the delta front slope (Tanabe et al. 2006; van den Bergh et al. 2007a).

During the late Holocene (from 2290 to 0 cal. year BP), shoals were continuously formed in the mouth of the Red River due to the lowering of sea level to the present level (Hori et al. 2004; van den Bergh et al. 2007a). Between 11.7 and $4.1 \mathrm{~m}$ in depth (2290 to 1720 cal. year BP), the sedimentation rate markedly increased to the highest value of $1.94 \mathrm{~cm} /$ year within the study area (figure $2 \mathrm{C}$ ), due to an increase in the progradation of the delta system (Hori et al. 2004; Tanabe et al. 2006). The facies showed an upward coarser succession with a concomitant increase in the sand fraction and decrease in silt and clay fractions (figure 2B). Results showed that the coarser-grained size predominated and were deposited in a shallower and higher energy hydrodynamic environment, and with high riverine input (Friedman 1961; McLaren and Bowles 1985; Zong et al. 2006). Additionally, $\mathrm{C} / \mathrm{N}$ ratios and $\delta^{13} \mathrm{C}$ values highly fluctuated between signatures of estuarine particulate organic matter and C3 plants (figures 4C, D and 6). Results indicated that the facies was deposited closely to the paleo-estuary, therefore, corresponding to the delta front platform (Duc et al. 2007), which may be encountered in water shallower than $10 \mathrm{~m}$ near the estuary and sandy mouth bar (van den Bergh et al. 2007b). It has been reported that the sediment volume supplied by the Red River during the last 2000 cal. year BP was much higher than the amount of sediment reworked or redistributed by waves and longshore current (Tanabe et al. 2006). Therefore, the concomitant increase in clay fraction (figure 2B) and decrease in $\mathrm{Md}$ values between 4.1 and $0.5 \mathrm{~m}$ in depth (from 1720 to 550 cal. year $\mathrm{BP}$ ) indicated decreasing tidal and wave energy (McLaren and Bowles 1985). $\mathrm{C} / \mathrm{N}$ ratios were $<10$, reflecting a greater presence of tidal particulate organic matter (Lamb et al. 2007). However, $\delta^{13} \mathrm{C}$ values varied from -27.7 to $-26.0 \%$ with a mean of $-27.0 \%$, showing the predominance of $\mathrm{C} 3$ plants (figure 6). The concomitant variation of $\mathrm{C} / \mathrm{N}$ ratios and $\delta^{13} \mathrm{C}$ values was similar to that viewed from a tidal flat in an earlier report by Wilson et al. (2005a), and therefore, was interpreted as tidal flat environment within this core section. Between $0.5 \mathrm{~m}$ to $0 \mathrm{~m}$ in depth (550 to 0 cal. year BP), sediments were reddish brown clay silt, fine sand and abundant fine roots that were similar to floodplain sediments and surface soils in core VN (Tanabe et al. 2006). The mud content markedly dropped to the lowest levels of $34 \%$. $\mathrm{C} / \mathrm{N}$ ratios and $\delta^{13} \mathrm{C}$ values were distinguished from the underlying sediment facies (figure 4), and thus were interpreted as flood plain. The present results might provide valuable information for simulating the environmental change and climate change, particularly, the geological evolution of the RRD.

\section{Conclusions}

In this paper, we analyzed environmental proxies of lithological characteristics, sedimentary texture and $\delta^{13} \mathrm{C}$ and $\mathrm{C} / \mathrm{N}$ ratios of a sediment core (VL01) that was mechanically drilled in the RRD to reconstruct the environmental changes during Holocene. The sudden shift of $\delta^{13} \mathrm{C}, \mathrm{C} / \mathrm{N}$ ratios, and lithological characteristics identified the erosion surface formed during the transgression at 
8860 cal. year BP. The concomitant variation of lithological characteristics, sediment grain-size distributions and geochemical proxies (LOI, TOC, $\mathrm{C} / \mathrm{N}, \delta^{13} \mathrm{C}$ ) suggested that the sediments in core VL-01 are divided into six depositional environments during the Holocene, consisting of sub- and inter-tidal flats, shelf-prodelta, delta front slope, delta front platform, tidal flat and flood plain. The $\delta^{13} \mathrm{C}$ and $\mathrm{C} / \mathrm{N}$ ratios in the core sediments allowed for conclusions on the sources of sedimentary organic matter that shifted from a dominance of mangroves and C3 plants at the sub- and intertidal flats to a dominance of marine phytoplankton at the shelf-prodelta and delta front slope during the transgression. The sediment sources of the delta front platform, tidal flat and flood plain were a mixture of C3 plants and phytoplankton, with the former becoming predominant. Results from this study showed that $\delta^{13} \mathrm{C}, \mathrm{C} / \mathrm{N}$ ratios, and sediment grain-size distributions together can be utilized as effective proxies in examining the paleoenvironment related to relative changes in sea level during the Holocene in the RRD. Additionally, $\delta^{13} \mathrm{C}$ and $\mathrm{C} / \mathrm{N}$ ratios allowed high-resolution sampling and provided an indirect measure of the marine-terrestrial interaction in the past.

\section{Acknowledgements}

We express our sincere thanks to Dr. Todd W Miller (US National Oceanic and Atmospheric Administration) for critical reviews and comments and English editing, which significantly improved this manuscript. This research is funded by the Vietnam National University, Hanoi (VNU) under project number QG.16.16.

\section{References}

Amano A, Iwamoto N, Inoue T and Inouchi Y 2006 Seafloor environmental changes resulting from nineteenth century reclamation in Mishou Bay, Bungo channel, southwest Japan; Environ. Geol. 50(7) 989-999.

Andrews J E, Greenaway A M and Dennis P F 1998 Combined carbon isotope and $\mathrm{C} / \mathrm{N}$ ratios as indicators of source and fate of organic matter in a poorly flushed, tropical estuary: Hunts Bay, Kingston harbour, Jamaica; Estuarine Coast. Shelf. Sci. 46(5) 743-756.

Blott S J and Pye K 2001 GRADISTAT: A grain size distribution and statistics package for the analysis of unconsolidated sediments; Earth. Surf. Proc. Land. 26(11) $1237-1248$.
Chan F K S, Mitchell G, Adekola O and McDonald A 2012 Flood risk in Asia's urban mega-deltas: Drivers, impacts and response; Environ. Urban. Asia 3(1) 41-61.

Cloern J E, Canuel E A and Harris D 2002 Stable carbon and nitrogen isotope composition of aquatic and terrestrial plants of the San Francisco Bay estuarine system; Limnol. Oceanogr. 47(3) 713-729.

Duc D M, Nhuan M T, Ngoi C V, Nghi T, Tien D M, Weering T C E and Bergh G D 2007 Sediment distribution and transport at the nearshore zone of the Red River delta, northern Vietnam; J. Asian Earth Sci. 29 558-565.

Elizabeth A V M, Jeremy M L, Melanie J L, Michael J B and Carol A 2007 Assessment of $\delta^{13} \mathrm{C}$ and $\mathrm{C} / \mathrm{N}$ ratios in bulk organic matter as palaeosalinity indicators in Holocene and Lateglacial isolation basin sediments, northwest Scotland; J. Quat. Sci. 22(6) 579-591.

Friedman G M 1961 Distinction between dune, beach, and river sands from their textural characteristics; J. Sedim. Res. 31(4) 514-529.

He B, Dai M, Huang W, Liu Q, Chen H and Xu L 2010 Sources and accumulation of organic carbon in the Pearl River estuary surface sediment as indicated by elemental, stable carbon isotopic, and carbohydrate compositions; Biogeosci. 7(10) 3343-3362.

Hedges J I, Clark W A, Quay P D, Richey J E, Devol A H and Santos M 1986 Compositions and fluxes of particulate organic material in the Amazon River; Limnol. Oceanogr. 31(4) 717-738.

Hori K, Tanabe S, Saito Y, Haruyama S, Nguyen V and Kitamura A 2004 Delta initiation and Holocene sea-level change: Example from the Song Hong (Red River) delta, Vietnam; Sedim. Geol. 164(3-4) 237-249.

Lamb A L, Wilson G P and Leng M J 2006 A review of coastal palaeoclimate and relative sea-level reconstructions using $\delta^{13} \mathrm{C}$ and $\mathrm{C} / \mathrm{N}$ ratios in organic material; Earth-Sci. Rev. 75(1-4) 29-57.

Lamb A L, Vane C H, Wilson G P, Rees J G and MossHayes V L 2007 Assessing $\delta^{13} \mathrm{C}$ and $\mathrm{C} / \mathrm{N}$ ratios from organic material in archived cores as Holocene sea level and palaeoenvironmental indicators in the Humber estuary, UK; Mar. Geol. 244(1) 109-128.

Lambeck K and Chappell J 2001 Sea level change through the last glacial cycle; Science 292(5517) 679-686.

Le T P Q, Garnier J, Gilles B, Sylvain T and Minh C V 2007 The changing flow regime and sediment load of the Red River, Vietnam; J. Hydrol. 334 199-214.

Li Z, Saito Y, Matsumoto E, Wang Y, Tanabe S and Lan V Q 2006 Climate change and human impact on the Song Hong (Red River) delta, Vietnam, during the Holocene; Quatern. Int. 144(1) 4-28.

Liu K-K, Kao S-J, Hu H-C, Chou W-C, Hung G W and Tseng C-M 2007 Carbon isotopic composition of suspended and sinking particulate organic matter in the northern South China Sea - from production to deposition; Deep-Sea Res. Part II: Topical Studies in Oceanography 54(14) 1504-1527.

Liu R, Qin J and Mei X 2014 Sedimentary environment changes of the Ningshao plain since the later stage of the late Pleistocene: Evidence from palynology and stable organic carbon isotopes; Quatern. Int. 333 188-197.

Liu X, Rendle-Bühring R, Meyer I and Henrich R 2016 Holocene shelf sedimentation patterns off equatorial East 
Africa constrained by climatic and sea-level changes; Sedim. Geol. 331 1-11.

Lorente F L, Pessenda L C R, Oboh-Ikuenobe F, Buso Jr A A, Cohen M C L, Meyer K E B, Giannini P C F, de Oliveira P E, Rossetti D F, Borotti Filho M A, França M C, de Castro D F, Bendassolli J A and Macario K 2014 Palynofacies and stable $\mathrm{C}$ and $\mathrm{N}$ isotopes of Holocene sediments from Lake Macuco (Linhares, Espírito Santo, southeastern Brazil): Depositional settings and palaeonvironmental evolution; Palaeogeogr. Palaeocl. 415 69-82.

Maren D S and Hoekstra P 2005 Dispersal of suspended sediments in the turbid and highly stratified Red River plume; Cont. Shelf. Res. 25 503-519.

Mathers S and Zalasiewicz J 1999 Holocene sedimentary architecture of the Red River delta, Vietnam; J. Coastal Res. 15(2) 314-325.

McLaren P and Bowles D 1985 The effects of sediment transport on grain-size distributions; J. Sedim. Res. 55(4) $457-470$

Meyers P A and Elisabeth L-V 1999 Lacustrine sedimentary organic matter records of late Quaternary paleoclimates; J. Paleolimnol. 21(3) 345-372.

Milliman J D and Meade R H 1983 Worldwide delivery of river sediment to the oceans; J. Geol. 91(1) 1-21.

Müller A and Mathesius U 1999 The palaeoenvironments of coastal lagoons in the southern Baltic Sea, I. The application of sedimentary $\mathrm{C}_{\mathrm{org}} / \mathrm{N}$ ratios as source indicators of organic matter; Palaeogeogr. Palaeoecol. 145(1-3) 1-16.

Nghi T, Toan N Q, Minh N D and Van Vuong N 1991 Quaternary sedimentation of the principal deltas of Vietnam; J. South Asian Earth Sci. 6(2) 103-110.

Nicholls R J and Cazenave A 2010 Sea-level rise and its impact on coastal zones; Science 328(5985) 1517-1520.

O'Leary M H 1981 Carbon isotope fractionation in plants; Phytochemistry 20(4) 553-567.

Rajganapathi V, Jitheshkumar N, Sundararajan M, Bhat K and Velusamy S 2013 Grain size analysis and characterization of sedimentary environment along Thiruchendur coast, Tamilnadu, India; Arab J. Geosci. 6(12) 47174728.

Reotita J, Siringan F, Zhang J and Azanza R 2014 Paleoenvironment changes in Juag Lagoon, Philippines based on sedimentology, bulk geochemistry and stable isotopes and their implication to nutrification; Quat. Int. 333 110121.

Ta T K O, Nguyen V L, Tateishi M, Kobayashi I, Tanabe S and Saito Y 2002 Holocene delta evolution and sediment discharge of the Mekong River, southern Vietnam; Quat. Sci. Rev. 21(16) 1807-1819.

Tanabe S, Hori K, Saito Y, Haruyama S, Vu V P and Kitamura A 2003 Song Hong (Red River) delta evolution related to millennium-scale Holocene sea-level changes; Quat. Sci. Rev. 22(21-22) 2345-2361.
Tanabe S, Saito Y, Lan V Q, Hanebuth T J J, Lan N Q and Kitamura A 2006 Holocene evolution of the Song Hong (Red River) delta system, northern Vietnam; Sedim. Geol. 187(1-2) 29-61.

Tanaka G, Komatsu T, Saito Y, Nguyen D P and Vu Q L 2011 Temporal changes in ostracod assemblages during the past 10,000 years associated with the evolution of the Red River delta system, northeastern Vietnam; Mar. Micropaleontol. 81(3) 77-87.

Tjallingii R I K, Stattegger K, Stocchi P, Saito Y and Wetzel A 2014 Rapid flooding of the southern Vietnam shelf during the early to mid-Holocene; J. Quatern. Sci. 29(6) $581-588$.

Tue N T, Hamaoka H, Sogabe A, Quy T D, Nhuan M T and Omori K 2011 The application of $\delta^{13} \mathrm{C}$ and $\mathrm{C} / \mathrm{N}$ ratios as indicators of organic carbon sources and paleoenvironmental change of the mangrove ecosystem from Ba Lat Estuary, Red River, Vietnam; Environ. Earth Sci. 64(5) $1475-1486$.

Tue N T, Quy T D, Hamaoka H, Nhuan M T and Omori K 2012 Sources and exchange of particulate organic matter in an estuarine mangrove ecosystem of Xuan Thuy national park, Vietnam; Estuar. Coast. 35 1060-1068.

Tue N T, Dung L V, Nhuan M T and Omori K 2014 Carbon storage of a tropical mangrove forest in Mui Ca Mau national park, Vietnam; Catena 121 119-126.

van den Bergh G D, Boer W, Schaapveld M A S, Duc D M and van Weering T C E 2007a Recent sedimentation and sediment accumulation rates of the Ba Lat prodelta (Red River, Vietnam); J. Asian Earth Sci. 29 545-557.

van den Bergh G D, van Weering T C E, Boels J F, Duc D M and Nhuan M T 2007b Acoustical facies analysis at the Ba Lat delta front (Red River Delta, North Vietnam); J. Asian Earth Sci. 29 532-544.

Visher G S 1969 Grain size distributions and depositional processes; J. Sedim. Res. 39(3) 1074-1106.

Wanner H, Beer J, Bütikofer J, Crowley T J, Cubasch U, Flückiger J, Goosse H, Grosjean M, Joos F, Kaplan J O, Küttel M, Müller S A, Prentice I C, Solomina O, Stocker T F, Tarasov P, Wagner M and Widmann M 2008 Midto Late Holocene climate change: An overview; Quat. Sci. Rev. 27(19-20) 1791-1828.

Wilson G P, Lamb A L, Leng M J, Gonzalez S and Huddart D $2005 \mathrm{a} \delta^{13} \mathrm{C}$ and $\mathrm{C} / \mathrm{N}$ as potential coastal palaeoenvironmental indicators in the Mersey Estuary, UK; Quat. Sci. Rev. 24(18-19) 2015-2029.

Wilson G P, Lamb A L, Leng M J, Gonzalez S and Huddart D 2005b Variability of organic $\delta^{13} \mathrm{C}$ and $\mathrm{C} / \mathrm{N}$ in the Mersey Estuary, U.K. and its implications for sea-level reconstruction studies; Estuar. Coast. Shelf Sci. 64(4) 685-698.

Zong Y, Lloyd J, Leng M, Yim W S and Huang G 2006 Reconstruction of Holocene monsoon history from the Pearl River Estuary, southern China, using diatoms and carbon isotope ratios; Holocene 16(2) 251-263. 